\title{
ВСЕМИРНОЕ ФЕДЕРАЛИСТСКОЕ ДВИЖЕНИЕ: ЦЕЛИ И ПРОБЛЕМЫ
}

\author{
P.А.Тузмухамедов
}

В современном международном политологическом словаре понятие "федерализм" охватывает две автономные и в то же время взаимосвязанные сферы. Соответственно различают два смысла федерализма.

Одна сфера - государственно-правовая - возникла в XVII в. в Европе. Субъекты данной сферы - государства и государственные образования, которые федерируются, сохраняя при этом ту или иную степень автономии. Здесь в центре политической проблематики стоит вопрос о соотношении власти и суверенитета центра и субъектов федерации.

Вторая сфера - международная, точнее, глобальная. Ее субъектами являются народы и индивиды, они стремятся к объединению (в том числе и государственному) в глобальном масштабе для того, чтобы обесіечить более эффективную, чем это в состоянии сделать государства, демократизацию международных отношений. Этот федерализм, получивший наименование федералистского движения, - явление второй половины XX в. Здесь в центре политической проблематики стоит вопрос о создании глобального устройства мира, при котором каждый народ и каждый человек будет уверен в реальной гарантированности своих прав и свобод, осознает себя равноправным гражданином-и субъектом мира и права. Движение - Всемирное федералистское движение (ВФД) - полностью признает цели и принципы ООН и участвует ныне в выработке путей ее демократизации, реформирования.

Согласно концепции ВФД, обе сферы не противоречат, а взаимодополняют друг друта. Но они могут прийти в столкновение, если будет допущена абссолютизация одной из них (государственно-бюрократического суверенитета или, наоборот, отвержение государства).

В 1993 году на международной конференции в Казани практически впервые на официальном уровне рассматривались вопросы ВФД. Ранее в нашей стране федералистское движение считалось одним из "происков империализма". Поэтому факт работы специальной Секции по ВФД явился бесспорным свидетельством демократизации общественного развития и доказательством поступательного процесса развития политико-ментального уровня жизни в Татарстане. Одновременно это стало знамением тех историчес-

* Профессор, член Совета Всемирного федералистского движения с 1991 года. 
ких перемен в России, которые наступили после августа 1991 года.

Что же представляет собой Всемирное федералистское движение? Возникло оно в 30-x годах XIX в. в Англин и получило широкое развитие после второй мировой войны в ряде стран, прехде всего в США и Японии. В качестве свидетельства его высокой международной политической активности можно указать на то, что оно регулярно корректирует свои уставные акты в соответствии с изменениями в мире. Таким образом, возникнув на волне послевоенной демократизации, оно пережило впоследствии "холодную войну" и вошло затем в мир, на горизонтах которого появились очертания тех перспектив, за которые оно выступает с момента своего основания. Последние коррективы были внесены 20-м Конгрессом в 1987 году (Филадельфия, США). Тогда же был принят другой основополагающий акт двихения - Заявление о целях всемирных федералистов, - прилагаемый ниже.

Согласно обоим документам, "суть всемирного федерализма в том, чтобы добиваться придания международным учреждениям такой степени правовых и политических полномочий, имея которые они могли бы справиться с проблемами, которые могут быть надлежаше решены только на глобальном уровне, и в то же время поддерживать суверенитет государств в вопросах, которые, по существу, входят в их внутреннюю компетенцию".

Согласно этим актам, главные цели ВФД состоят в том, чтобы:

a) стремиться к установлению такого мирового порядка, в котором "захонные права на самоопределение были бы сбалансированы и совместимы с коллективными правами сообшества на развитие и защиту общих ценностей человечества", и

б) добиться того, чтобы "не только правительства, но и отдельные личности признали для себя обязательным поддерживать и укреплять Всемирное право через верность следующим тезисам: именно гражданин является конечным и правомерным источником и субъектом полномочий Всемирного права; индивид, будь то глава правительства или рядовой гражданин, должен нести ответственность на онове Всемирного права за преступления против человечества".

Стремясь к всемирной федерации, ВФД особое внимание уделяет следуюшим задачам:

1. Взаимопонимание и дружба между мировыми культурами и мировоззрениями.

2. Прекрашение гонки вооружений и ликвидация всех видов оружия массового уничтожения.

3. Прекрашение применения или угрозы применения военной силы.

4. Уважение к основным правам и свободам человека.

5. Равное участие всех в мировой экономике и глобальных решениях, затрагивающих их жизнь. 
6. Защита общей для всех окружаюшей среды и сохранение экосистемы для последующих поколений.

7. Нарождение всемирного этноса и осознание Человечеством себя в качестве единой общности и каждым Человеком - в качестве гражданина мира.

Для решения этих задач ВФД подцерживает те трансгосударственные тенденции, которые способствуют созданию более совершенного мирового порядка и мирового сообшества. В частности, оно выступает за:

a) ахцентирование внимания на функциях и деятельности системы $\mathrm{OOH}$, на повышении ее демократичности, надежности и эффективности;

б) уважение к международному праву и его дальнейшее развитие с помощью таких механизмов, как ратификация государствами международных договоров и конвенций;

в) развитие ассоциирования и (или) федерирования государств в целях региональных или функциональных потребностей.

При достижении указанных выше целей и решении перечисленных задач ВФД руководствуется основным принципом - принципом субсидиарности, который означает:

- разделение политической власти и юрисдикции между различными уровнями управления;

- решение проблем на тех уровнях, на которых они возникают, по возможности на более низком, местном уровне.

Как сказано в Уставе и заявлении ВФД, "мы. признаем, что созидание мирового сообщества - такого, которое основано на подлинной справедливости и уважении различий, - является величайшим интеллектуальным, моралыным и политическим вызовом нашего времени".

Какие направления деятельности в этой связи ВФД считает злободневными? Их несколько:

1. Активное участие в проведении Декады международного права ООН (1989 - 1999 гт.), которая должна завершиться Всемирной конференцией по мирному решению международных споров.

2. Непосредственное участие в международных решениях проблем окружающей среды, в частности в деятельности созданной в 1992 году Комиссии ООН по устойчивому развитию, в работе которой могут участвовать и неправительственные организации, в том числе ВФД.

3. Создание в ООН, наряду с Генеральной Ассамблеей, Парламентской ассамблеи по образцу Европейской парламентской ассамблеи (т.е. составленной из представителей парламентов государств - членов Европейского совета) с тем, чтобы подлинные представители населения государств (не бюрократических структур) стали участниками принятия решений ООН. 
4. Повышение эффективности использования миротворческих сил $\mathrm{OOH}$ в интересах зашиты прав человека и народов.

5. Ускорение создания Международного уголовного суда, проект статута которого уже подготовлен Комиссией ООН по мехдународному праву, с тем чтобы официально в утоловном порядке привлекать $\mathrm{K}$ ответственности тех, кто посягает на защицаемые международным правом права и свободы человека и народов.

6. Реформировать Совет Безопасности так, чтобы он был более представительным в условиях нового мира, столь изменившегося спустя полвека после того, как Совет был создан в 1945 году в качестве главного органа $\mathrm{OOH}$, ответственного за обеспечение международного мира и безопасности.

7. Осушествление проекта "Наша планета - в каждом школьном классе", нацеленного на воспитание в подрастающем поколении чувства общечеловеческой общности при полном уважении $\mathbf{k}$ расовым, этническим, религиозным, языковым и иным различиям людей и народов.

8. Деятельность Комиссии по глобальному управлению.

Последние два направления деятельности ВФД связаны с ее более узкими целями и задачами.

По каждому из этих направлений ВФД имеет детальные перспективные планы.

Имея консультативный статус прн ООН, ВФД весьма активно участвует в системе ООН по реализации своих целей и решению задач.

Главным органом ВФД является Конгресс, созываемый раз в 4 года. Последний - 21-й Конгресс - состоялся в 1991 году в Амстердаме*. На нем был избран новый Президент Движения - лауреат Нобелевской премии, известный актер и драматург Питер Устинов. Оперативными органами, выполняющими решения Конгресса, являются: Совет, Исполком, проводящие заседания раз в год, и постоянно функционирующий Международный секретариат в Нью-йорке.

Членство в ВФД - индивидуальное и коллективное (организации и иные группы), без какой-либо дискриминации, при условии согласия с целями и задачами ВФД.

На практике в ВФД, помимо индивидуальных членов, существуют следующие категории членов:

национальные организации (их в 1994 году было 16 - из Австралии, Бангладеш, Башкортостана, Бельгии, Великобритании, Дании, Индии, Италии, Кореи, Нидерландов, Норвегии, Франции, США, Швейцарии, Швеции, Японии),

* 22-й Конгресс ВФД состоится 22 - 26 охтября 1995 г. в СанФранциско. 
ассоциированные организации (их 15 - из Дании, Индии, Италии, Кореи, Маврикия, Пакистана, России - три московские ассоциации, Чехии и США - пять ассоциаций),

молодежные организации (две национальные и две международные), парламентские группы (Японская парламентская группа за Всемирное федеративное правительство).

Для вступления в ВФД требуется письменное заявление о членстве в одной из перечисленных категорий, устав ассоциации, резюме на английском или французском языке, список $5-6$ руководяших лиц ассоциации и информация о ее деятельности за последние годы.

ВФД выпускает различные издания, в том числе периодический журнал "Новости всемирного федералиста".

Сказанное выше о ВФД для живущих на территории бывшего СССР может показаться чем-то почти запредельным. Но это воздействие инерции, синдрома нашего прошлого, когда мы, участвуя в международных отношениях как государство, жили изолированно, за "железным занавесом".

Одна из сегодняшних реалий - международно-правовая субъектность России и связанные с этим дополнительные обязательства перед своим народом и грахданами, необходимость соответствия этих обязательств международным стандартам.

Другая реалия - резкий рост гражданского и международноправового сознания народов и индивидов, свидетельством чего стало, в частности, учреждение в Казани отделения Организации непредставленных страи и народов, а также создание Конфедерации народов Кавказа, Ассоциации народов Поволжья и других объединений народов России.

Следуюшая реалия - повышение активности Европейского федералистского движения по мере усиления объединительных тенденций в Европе, особенно после подписания Маастрихтского договора.

Наконец, реальна и необходимость сочетания федерализма, связанного с государственным устройством России, и федерализма народов и индивидов на уровне глобального объединения в цеелях гарантирования их прав и свобод в соответствии с целями и принципами Устава ООН.

В силу причины, указанной в начале статьи, не только участие во Всемирном федералистском движении, но даже рассказ о нем, пропаганда на территории СССР были невозможны. Ныне ситуация изменилась. В России стали возникать отдельные группы и ассоциации федералистов. Большим стимулом стала конференция "Федерализм: глобальные и российские измерения", проведенная по инициативе международной неправительственной организации "Юристы СНГ за сотрудничество в Азиатско-Тихоокеанском регионе" (СЮСАТР) в Казани в сентябре 1993 года. В процессе работы секций конферен- 
ции по ВФД возникли две национальные организации федералистов - Башкирская ассоциация федералистов (БАФ) и Татарстанская ассоциация федералистов (ТАФ). Первая уже зарегистрирована в Уфе, и ее делегация приняла участие в работе Совета ВФД в 1994 году в кантоне Гларус (Швейцария). На этой сессии Совета БАФ была принята в ВФД в качестве "национальной организации". Сессия приняла решение провести очередную сессию в Уфе в 1996 году. 22-й Конгресс состоится летом 1995 года в Сан-Франциско.

Башкирская ассоциация федералистов - первая "национальная организация" из бывшего СССР в составе ВФД. Еще ранее - с начала 90-х годов - в Движение в качестве "ассоциированных членов" вошли несколько организаций из России. Активна в ВФД и деятельность СЮСАТР.

В 1994 году в Казани был подготовлен первый ежегодник "Федералист Поволжья". Помимо статей он содержит базовые нормативные акты ВФД и полезен как справочник по Всемирному федералистскому движению. Авторами являются специалисты из Мосқвы, Казани, СанФранциско и Оттавы. Готовится ежегодник 1995 года. Будем рады, если и читатели данного журнала пожелают принять участие в работе над ежегодником. Статьи и материалы просим посылать по адресам: 119889, Москва, Пречистенка, 10, СЮСАТР, профессору Р.А. Тузмухамедову; 119841, Москва, Знаменка, 10, Институт государства и права РАН, профессору Р.А. Тузмухамедову; факсы: 291-8574, 202-1208. 